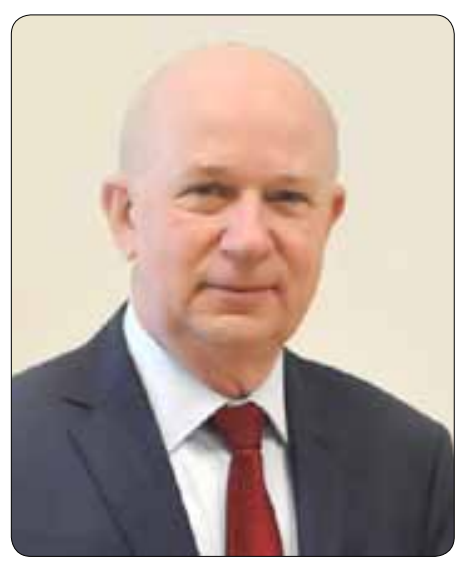

\title{
List Redaktora Naczelnego
}

Przed Państwem 1. numer 100. tomu „Lekarza Wojskowego”. Przez sto lat pismo zmieniało szatę graficzną, liczbę wydań w ciągu roku, ale trwało nawet w najtrudniejszych czasach burzliwej historii i przetrwało do dziś. W „Lekarzu Wojskowym” publikowali wybitni polscy naukowcy, lekarze - nie tylko w mundurach. Mam nadzieję, że tak pozostanie. Zapraszamy do współpracy wszystkich kolegów, także tych spoza Polski, rozrzuconych po całym świecie.

Otwieramy nowy rozdział. Po przeprowadzeniu szeregu zapowiadanych zmian (nowa szata graficzna i strona internetowa, nadawanie artykułom numerów DOI, uruchomienie elektronicznego systemu do składu i redakcji artykułów), zaczęliśmy wydawać 100. tom naszego pisma. „Lekarz Wojskowy" znalazł się w ministerialnym wykazie czasopism naukowych, co oznacza, że za opublikowany w nim artykuł autorom będzie przyznane 20 punktów. Okres przygotowań do tych zmian to praca całego zespołu redakcyjnego. Wszystkim, którzy byli w nią zaangażowani oraz tym, którzy trzymali za nas kciuki - bardzo dziękuję.

W 1. numerze, tak jak zapowiadaliśmy, znajdą Państwo prace poglądowe, oryginalne, opisy przypadków, wywiad, sprawozdanie z konferencji oraz list do redakcji. Tematyka szeroka: od prac z zakresu nauk podstawowych po klinikę i problemy z zakresu bezpieczeństwa.

Na uwagę zasługują prace poświęcone: profilaktyce poekspozycyjnej tężca - temat ciągle obecny w działalności Szpitalnych Oddziałów Ratunkowych i w „medycynie wojskowej”, zaburzeniom autofagii oraz przebiegowi kleszczowego zapalenia mózgu na podstawie opisu przypadku. Temat pandemii COVID-19 poruszamy $w$ artykule omawiającym podejście rządów różnych państw do szczepień.

Mam nadzieję, że szata graficzna pisma i strona internetowa przypadną Państwu do gustu. Mogę zapewnić, że zespół redakcyjny dołoży wszelkich starań, aby artykuły publikowane w „Lekarzu Wojskowym" były przydatne w praktyce kolegów lekarzy i prezentowały coraz wyższy standard.

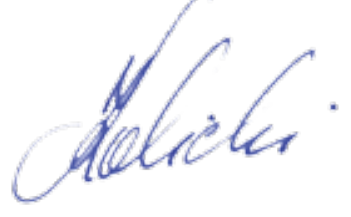

prof. dr hab. n. med. Bolestaw Kalicki 